\title{
Current perspectives in stem cell therapies for osteoarthritis of the knee
}

\section{Gi Beom Kim, Oog-Jin Shon}

Department of Orthopedic Surgery, Yeungnam University College of Medicine, Daegu, Korea

Received: March 12, 2020

Revised: April 1, 2020

Accepted: April 1, 2020

Corresponding author:

Oog-Jin Shon

Department of Orthopedic Surgery,

Yeungnam University College of

Medicine, 170 Hyeonchung-ro,

Nam-gu, Daegu 42415, Korea

Tel: +82-53-620-3640

Fax: +82-53-628-4020

E-mail: maestro-jin@hanmail.net
Mesenchymal stem cells (MSCs) are emerging as an attractive option for osteoarthritis (OA) of the knee joint, due to their marked disease-modifying ability and chondrogenic potential. MSCs can be isolated from various organ tissues, such as bone marrow, adipose tissue, synovium, umbilical cord blood, and articular cartilage with similar phenotypic characteristics but different proliferation and differentiation potentials. They can be differentiated into a variety of connective tissues such as bone, adipose tissue, cartilage, intervertebral discs, ligaments, and muscles. Although several studies have reported on the clinical efficacy of MSCs in knee OA, the results lack consistency. Furthermore, there is no consensus regarding the proper cell dosage and application method to achieve the optimal effect of stem cells. Therefore, the purpose of this study is to review the characteristics of various type of stem cells in knee OA, especially MSCs. Moreover, we summarize the clinical issues faced during the application of MSCs.

Keywords: Knee joint; Mesenchymal stem cells; Osteoarthritis; Stem cells

\section{Introduction}

Osteoarthritis (OA) is a degenerative joint disease characterized by loss of cartilage, osteophyte formation, and periarticular bone change, resulting in disability $[1,2]$. In order to establish the disease-modifying strategies of $\mathrm{OA}$, it is necessary to understand the biomolecular features seen in OA circumstance. Increased proinflammatory cytokines such as interleukin-1 or tumor necrosis factor- $\alpha$, decreased growth factors such as transforming growth factor-beta (TGF- $\beta$ ), activated matrix metalloproteinase, and ultimate chondrocyte senescence can be observed at the molecular level [3-5] (Fig. 1). Although disease-modifying OA strategies that block inflammatory pathways and enhance cartilage protective function have been developed recently [6,7], their effects on preventing the progression of OA have been still unsatisfactory, and it is particularly difficult to achieve ultimate cartilage regeneration [8].
Meanwhile, since articular cartilage has a limited capacity for spontaneous healing, once damaged, it may eventually progress to OA [9]. Numerous attempts for the regeneration of focal cartilage defect have been made. Depending on the degree of defect size, various surgical options have been used, including multiple drilling, microfracture, abrasion chondroplasty, autologous chondrocyte implantation, and osteochondral autologous transplantation [10-13]. However, there has been no optimal regenerative method for cartilage in knee OA.

Recently, mesenchymal stem cells (MSCs) have been in the spotlight for their disease-modifying and chondrogenic potential along with their ease of harvesting, safety, and differentiation potential into cartilage $[14,15]$. Moreover, MSCs have been known to have paracrine and immunomodulatory effects through the secretion of cytokines and growth factors [16-19].

Therefore, considering the immunomodulatory and regenerative effect, stem cell therapies might be a promising line of treat-

Copyright (C) 2020 Yeungnam University College of Medicine

This is an Open Access article distributed under the terms of the Creative Commons Attribution Non-Commercial License (http://creativecommons.org/licenses/by-nc/4.0/) which permits unrestricted non-commercial use, distribution, and reproduction in any medium, provided the original work is properly cited. 


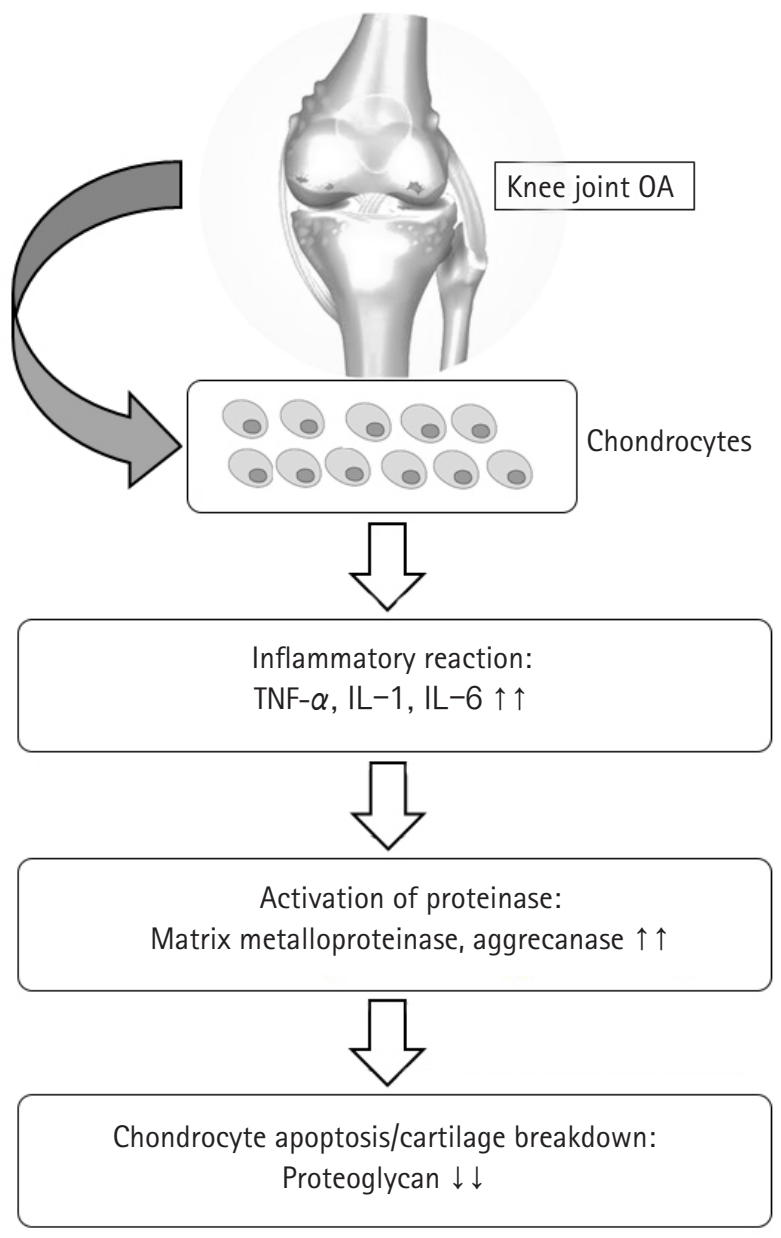

Fig. 1. Molecular mechanisms of osteoarthritis (OA). TNF, tumor necrosis factor; IL, interleukin. ment for knee OA. The purpose of this study was to review the characteristics of various type of stem cells in knee OA, especially based on MSCs. Moreover, we summarized the clinical issues for application of MSCs (Fig. 2).

\section{General characteristics of stem cells}

In general, stem cells can be divided into two major groups: (1) embryonic stem cells (ESCs) from the inner cell mass of blastocyst, with totipotency or pluripotency; (2) adult stem cells (tissue-specific stem cells) from specific organ, with multipotency $[20,21]$. Although adult stem cells have usually more restricted differentiation capacity compared to ESCs, they exhibit some advantages including safety, easy derivation, and tissue-specific differentiation potential [22]. Among them, MSCs appears to be the promising candidates.

MSCs are multipotent progenitor cells that can be obtained from bone marrow, adipose tissue, synovial membrane, and articular cartilage [23]. Several studies report their multidirectional differentiation potential $[24,25]$. Particularly, autologous MSCs can be easily harvested and applied in clinical settings, and allogenic cells can be utilized $[14,19]$. Culture expansion may be required to maximize their clinical effect [14], although that may result in functional deterioration, mutation, and tumorigenesis as passage progresses. Nevertheless, MSCs can be cultivated and amplified while maintaining their potential, and differentiated into a variety of connective tissues such as bone, adipose tissue,

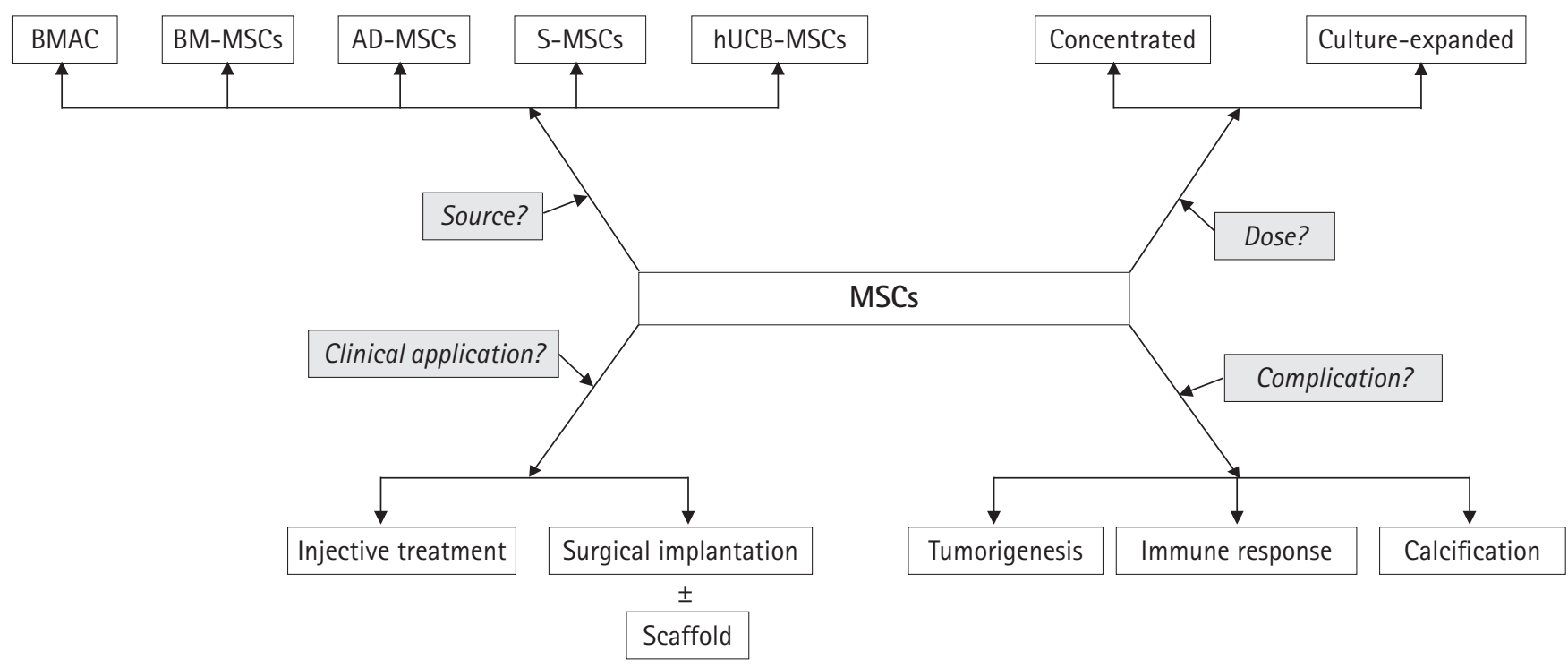

Fig. 2. Considerations for clinical application of MSCs. BMAC, bone marrow aspirate concentrate; MSC, mesenchymal stem cell; BM, bone marrow-derived; $A D$, adipose tissue-derived; $S$, synovium-derived; $h U C B$, human umbilical cord blood-derived. 
cartilage, intervertebral discs, ligaments, and muscles [26,27]. Owing to their inherent ability for self-renewal, proliferation, and differentiation toward mature tissues, MSCs could have promising applications in cell therapy and regenerative medicine [28]. The Mesenchymal and Tissue Stem Cell Committee of the International Society for Cellular Therapy proposed the definition of MSC via the following minimal set of criteria: (1) being plastic-adherent in standard culture conditions; (2) expressing CD105, CD73, and CD90 at their surface; while (3) lacking CD45, CD34, CD14, CD79 $\alpha$, and HLA-DR; and (4) being able to differentiate into osteoblasts, adipocytes, and chondrocytes in vitro [27].

\section{Bone marrow-derived mesenchymal stem cells}

Bone marrow-derived mesenchymal stem cells (BM-MSCs) have been widely studied for OA treatment because of several advantages, including high expansion ability, and differentiation potential into cartilage [29-31]. Furthermore, due to easy harvesting from autologous bone marrow, they are cost-effective as compared to other types of MSCs. Several studies have reported favorable clinical outcomes in patients with knee OA who underwent intra-articular injection or surgical implantation using autologous BM-MSCs (Table 1) [31-35]. However, donor site pain, limited number of obtainable cells $(0.001 \%$ of all nucleated cells in bone marrow), and decreased differentiation potential with increase in donor age are a few limitations while using BM-MSCs $[31,36]$.
Bone marrow aspiration from anterior or posterior iliac crest can be performed with local anesthesia under ultrasonographic or fluoroscopic guidance to improve accuracy and efficiency [37].

Meanwhile, bone marrow aspirate concentrate (BMAC), which contains abundant nucleated cells and cytokines has been widely applied to the treatment of knee OA. It contains several factors involved in the healing process such as platelet-derived growth factor, TGF- $\beta$, vascular endothelial growth factor, and fibroblast growth factor $[17,38]$. BMAC can be easily extracted by via FDA approved commercialized kits and this process condenses the buffy coat containing mononuclear cells and increases the number of MSCs relative to baseline [39]. Recently, it is widely used in various orthopedic fields such as nonunion, osteonecrosis and sports injuries.

Centeno et al. [40] reported encouraging clinical outcomes with a low rate of adverse effects in autologous BMAC for intra-articular injection with or without adipose grafts in patients with knee OA. Additionally, significantly better results were observed in patients with Kellgren-Lawrence (K-L) grades I or II than in patients with K-L grades III or IV. Other studies have also reported positive clinical outcomes with simple iintra-articular injections of BMAC $[41,42]$. Contrastingly, in a recently conducted prospective randomized controlled trial, Shapiro et al. [42] did not report encouraging outcomes of BMAC as compared to the control group. BMAC studies in OA patients have not yet shown consistent results. Further researches comprising well-designed, randomized, controlled trials with larger sample sizes are needed to elucidate the exact mechanism of BMAC.

Table 1. Details of the clinical studies of BM-MSCs in knee OA

\begin{tabular}{|c|c|c|c|c|c|c|c|c|}
\hline Study & $\begin{array}{l}\text { Study design } \\
\text { (no. of cases) }\end{array}$ & $\begin{array}{c}\text { Mean age } \\
(y r)\end{array}$ & $\begin{array}{c}\text { Mean F/U } \\
(\mathrm{mo})\end{array}$ & Delivery method & $\begin{array}{l}\text { Cell population } \\
\text { (cells/mL) }\end{array}$ & $\begin{array}{l}\text { Additional } \\
\text { factor }\end{array}$ & Outcome & Complication \\
\hline $\begin{array}{c}\text { Wakitani et al. } \\
\text { (2011) [33] }\end{array}$ & Case series (45) & 50 & 75 & $\begin{array}{l}\text { Two-stage surgical im- } \\
\text { plantation }\end{array}$ & $5.0 \times 10^{6}$ & $\begin{array}{l}\text { Collagen sheet } \\
\text { from porcine } \\
\text { tendon }\end{array}$ & $\begin{array}{l}\text { No serious complica- } \\
\text { tions such as tumor or } \\
\text { infection }\end{array}$ & - \\
\hline $\begin{array}{l}\text { Davatchi et al. } \\
\text { (2011) [34] }\end{array}$ & Case series (4) & 57.8 & 12 & Intra-articular injection & $8.0-9.0 \times 10^{6}$ & - & $\begin{array}{l}\text { Pain, walking time, and } \\
\text { the number of stairs to } \\
\text { climb were improved }\end{array}$ & - \\
\hline $\begin{array}{l}\text { Wong et al. } \\
\text { (2013) [32] }\end{array}$ & $\begin{array}{l}\text { Prospective RCT } \\
\text { (28 MSCs+HA } \\
\text { vs. } 28 \mathrm{HA})\end{array}$ & 51 & 24 & Intra-articular injection & $1.46 \pm 0.29 \times 10^{7}$ & $\begin{array}{l}\text { Microfx- } \\
\text { +MOWHTO }\end{array}$ & $\begin{array}{l}\text { Better clinical outcomes } \\
\text { and MRI in MSCs } \\
\text { group }\end{array}$ & - \\
\hline $\begin{array}{l}\text { Orozco et al. } \\
\text { (2013) [31] }\end{array}$ & Case series (12) & 49 & 12 & Intra-articular injection & $4.0 \times 10^{7}$ & - & $\begin{array}{l}\text { Improvement in pain } \\
\text { relief and WOMAC; } \\
\text { improvement of carti- } \\
\text { lage quality on MRI }\end{array}$ & - \\
\hline $\begin{array}{c}\text { Davatchi et al. } \\
\text { (2016) [35] }\end{array}$ & Case series (3) & 57.8 & 60 & Intra-articular injection & $8.0-9.0 \times 10^{6}$ & - & $\begin{array}{l}\text { Previous parameters } \\
\text { gradually deteriorated, } \\
\text { but better than base- } \\
\text { line }\end{array}$ & - \\
\hline
\end{tabular}

BM-MSCs, bone marrow-derived mesenchymal stem cells; OA, osteoarthritis; F/U, follow-up; RCT, randomized controlled trial; HA, hyaluronic acid; Microfx, microfracture; MOWHTO, medial open-wedge high tibial osteotomy; MRI, magnetic resonance image; WOMAC, the Western Ontario and McMaster Universities Osteoarthritis Index. 


\section{Adipose tissue-derived mesenchymal stem cells}

Adipose tissue, along with bone marrow, has been the most frequently used source for isolating MSCs [43]. Adipose tissue is abundant and easily accessible, making it a reliable site for stem cell isolation. It has copious numbers of MSCs (approximately $0.5 \times 10^{4}-2.0 \times 10^{5} / 1 \mathrm{~g}$ fat) compared to BM-MSCs and their differential capacity is relatively less affected by donor age.

The specific premade solution is usually infiltrated into the subcutaneous tissue of the abdominal region through a tumescent technique, and then, a conventional abdominal liposuction is performed using blunt cannulas [44]. Enzymatic digestion of fat tissue is the most used isolation technique to obtain adipose tissue-derived mesenchymal stem cells (AD-MSCs) [45]. The extracted fat tissue is digested with enzyme (collagenase, dispase, or trypsin) to generate the stromal vascular fraction (SVF) that contains AD-MSCs and other endothelial and hematopoietic cells $[46,47]$. Among them, only the plastic-adherent, cultured and serially passaged multipotent cell populations are termed as $\mathrm{AD}$ MSCs [48]. Meanwhile, non-enzymatic digestion, including mechanical procedures such as centrifugation and filtration is sometimes used. However, the range of yields shows high variation [49].

Several studies have reported encouraging clinical results for intra-articular injection of AD-MSCs in knee OA patients (Table 2) [14,50-53]. Lee et al. [50] reported that intra-articular injection of culture expanded AD-MSCs $\left(1 \times 10^{8}\right.$ cells $)$ showed satisfactory functional improvement and pain relief in patients with knee OA through a prospective randomized controlled trial. Nonetheless, $\mathrm{AD}$-MSCs have some disadvantages such as relatively lower chondrogenic potential and donor site morbidity [54].

SVF also can be obtained via enzymatic digestion and differential centrifugation of adipose tissue. SVF consists of a heterogeneous mesenchymal population of cells that includes not only adipose stromal and hematopoietic stem cells but also endothelial cells, erythrocytes, fibroblasts, lymphocytes, monocyte/macro-phages and pericytes (Table 3) [45,55]. Despite a highly heterogenous composition and low stem cell proportion, some studies have reported favorable clinical outcomes of SVF in knee OA due to their potential and ease of use $[56,57]$.

\section{Synovium-derived mesenchymal stem cells}

Synovium-derived mesenchymal stem cells (S-MSCs) have attracted considerable attention due to their high chondrogenic po-

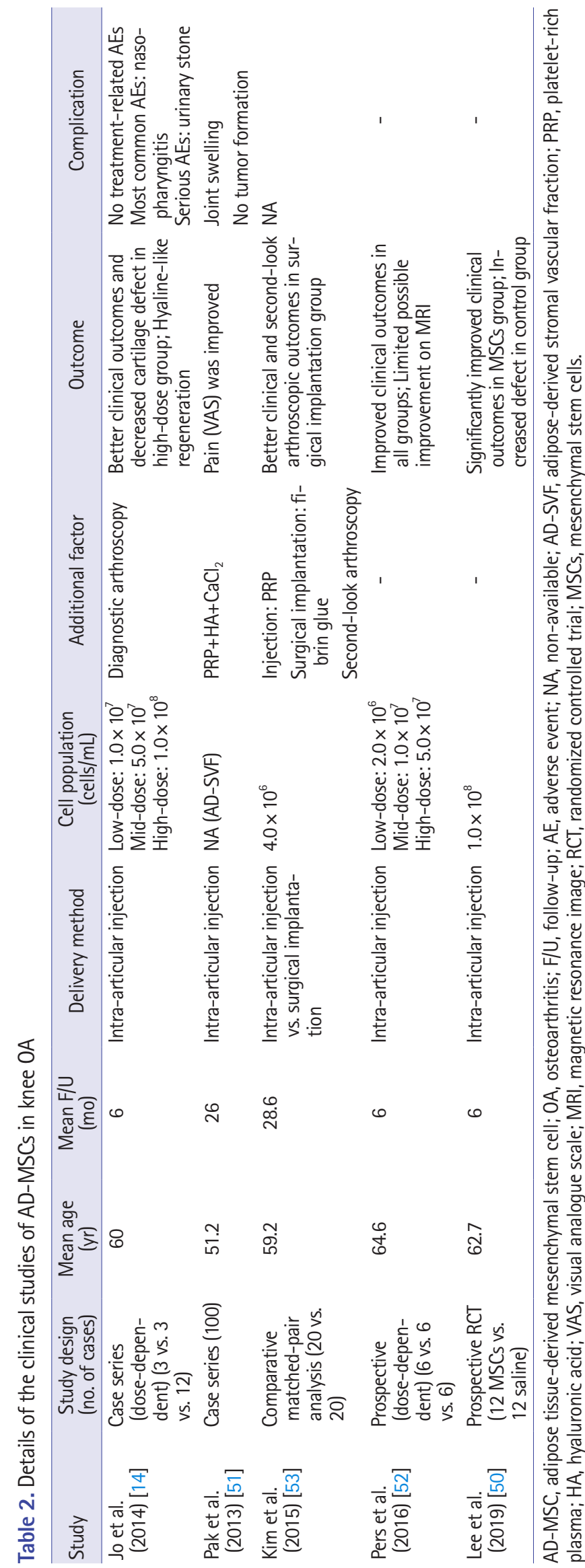


Table 3. Cell population in stromal vascular fraction

\begin{tabular}{lc}
\hline Variable & Percentage (\%) \\
\hline Stromal cell & $15-30$ \\
Hematopoietic-lineage cell & \\
Stem and progenitor cell & $<0.1$ \\
Granulocyte & $10-15$ \\
Monocyte & $5-15$ \\
Lymphocyte & $10-15$ \\
Endothelial cell & $10-20$ \\
Pericyte & $3-5$
\end{tabular}

tential and less hypertrophic differentiation than BM-MSCs $[58,59]$. Embryologically, S-MSC-derived chondrocytes and articular chondrocytes share similar gene expression profile [60]. They may prove to be the optimal cell source of MSCs as native nature to the joints. Kubosch et al. [58] reported that S-MSCs play an important role in joint homeostasis and possibly in natural cartilage repair. However, most of their evidence was limited to preclinical studies [61]. Only one retrospective study has reported the results of S-MSCs in human OA of the knee joint [62]. They reported clinical improvement and secure defect filling confirmed using second-look arthroscopy and magnetic resonance image, 48 months postoperatively. Further researches are needed to elucidate the interaction of S-MSCs and chondrocytes, and the promising role of S-MSCs in cartilage tissue engineering.

\section{Human umbilical cord blood-derived mesenchymal stem cells}

Umbilical cord compartments including Wharton's jelly, perivascular tissue, and umbilical cord blood (UCB) can be utilized to isolate MSCs [43,63]. Umbilical cord-derived MSCs can be obtained through pain-free collection methods with fewer ethical issues. An experimental comparative study [64] confirmed that UCB-MSCs have biological advantages in comparison to bone marrow or adipose tissue, including higher rate of proliferation and clonality, retardation of senescence, and superior anti-inflammatory effect.

Recently, clinical outcomes of human UCB-MSCs (hUCBMSCs) for cartilage regeneration have been reported [65-67], and their medicinal product mixed with hyaluronic acid (Cartistem; Medipost, Seongnam, Korea) has been widely applied in clinical settings. hUCB-MSCs are also isolated in a non-invasive manner and have the advantage of being hypoimmunogenic. Moreover, they show a hyaline-like histological morphology [67]. Park et al. [65] reported that an hUCB-MSC-based product appeared safe and effective for the regeneration of hyaline-like cartilage in $\mathrm{OA}$ of the knee after 7 years of follow-up. In our institution, commercialized hUCB-MSCs were performed on OA of the knee to obtain favorable clinical outcomes and highly qualified regeneration (Fig. 3).

\section{Clinical issues for application of mesenchymal stem cells}

There is no consensus on the optimal dose or cell number to achieve the utmost effect of stem cells. The optimal dose of MSC implantation for cartilage regeneration has not yet been established. In a dose-dependent prospective study, Jo et al. [14] reported that significant clinical improvement was shown only in the high dose group $\left(1 \times 10^{8}\right.$ cells $)$. Based on this result, culture expansion may be needed to obtain the optimal effect of MSCs.

Treatment strategies for clinical application may also be one of the issues faced by clinicians. Injective treatment is relatively efficient because it is easy to apply and does not require hospitalization, but precise delivery to target site may be difficult [54]. Conversely, surgical implantation allows direct delivery to the lesion site, but requires hospitalization and is a more invasive approach. Another option is to mix MSCs with biodegradable scaffolds followed by surgical implantation. The three-dimensional scaffold maintains the phenotype of differentiated chondrocytes, promotes improved chondrogenesis through uniform cell distribution, and reduces the risk of chondrocyte leakage [68]. Scaffold materials include hyaluronic acid, collagen derivatives, agarose, fibrin glue, and chitosan [69]. However, chondrocyte dedifferentiation, apoptotic cell leakage, inadequate cell distribution, and low differentiation have been reported in scaffold-based studies [70].

Potential risks of MSCs in clinical use, such as tumorigenesis, immune response, and heterotrophic calcification are also considerable issues [71]. Therefore, it should be recognized that such risk of MSC-mediated abnormal reactions might occur in some cases, and mandating a careful assessment of the patient's condition. Further research is also needed to guarantee the safety of MSCs. Each type of MSCs is summarized in Table 4.

\section{Other advanced techniques}

\section{Induced pluripotent stem cell}

Induced pluripotent stem cells (iPSCs) are also becoming a promising cell source for stem cell-based therapy [72]. They are a kind of stem cells established in the laboratory that can be reprogrammed into somatic cells. Although therapeutic models of neurological and cardiovascular diseases using iPSCs have been reported $[73,74]$, the research using iPSCs in orthopedic fields is still in its nascent stages, particularly for cartilage regeneration. iP- 

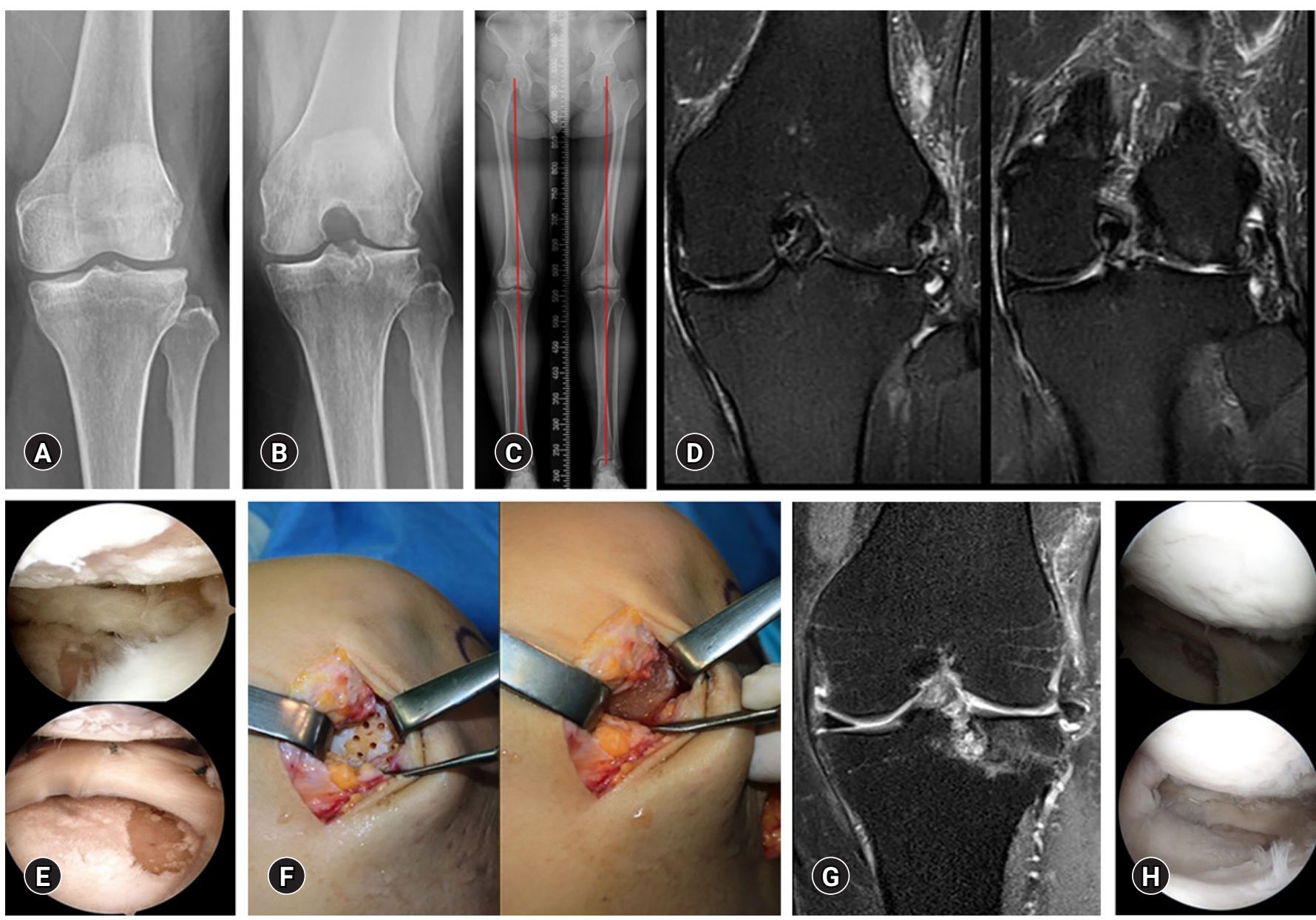

Fig. 3. (A, B) Kellgren-Lawrence grade III osteoarthritis is observed in the left knee anteroposterior and $45^{\circ}$ flexion standing radiographs in a 49-year-old woman. (C) The scanography image shows neutral alignment of the both lower extremities. (D, E) Coronal T2weighted fat suppressed magnetic resonance image (MRI) and arthroscopy show the focal chondral defects of International Cartilage Repair Society (ICRS) grade IV in the lateral femoral condyle and lateral tibial plateau. (F) Surgical implantation is performed using a commercialized mixture of human umbilical cord blood-derived mesenchymal stem cells and hyaluronic acid gel (Cartistem). (G, H) The coronal T2-weighted fat suppressed MRI and second-look arthroscopy confirm regenerated cartilage at 18 months after surgery.

Table 4. Summary of advantages and disadvantages of each MSC

\begin{tabular}{|c|c|c|c|c|}
\hline & BM-MSC & AD-MSC & S-MSC & hUCB-MSC \\
\hline Advantage & $\begin{array}{l}\text { High chondrogenic and osteo- } \\
\text { genic potential } \\
\text { Good expansion ability }\end{array}$ & $\begin{array}{l}\text { Easily accessible, reliable for isolation } \\
\text { Plentiful number of cells } \\
\text { Less affected by donor age }\end{array}$ & $\begin{array}{l}\text { Greater chondrogenic potential } \\
\text { (same embryological origin as } \\
\text { cartilage) }\end{array}$ & $\begin{array}{l}\text { Direct delivery on defect } \\
\text { Hypoimmunogenic } \\
\text { Histology: hyaline-like cartilage }\end{array}$ \\
\hline Disadvantage & $\begin{array}{l}\text { Donor site pain } \\
\text { Limited number of cells } \\
\text { More affected by donor age }\end{array}$ & $\begin{array}{l}\text { Relatively lower chondrogenic po- } \\
\text { tential } \\
\text { Donor site morbidity (hematoma, in- } \\
\text { fection) }\end{array}$ & $\begin{array}{l}\text { Less osteogenic potential } \\
\text { Not easy to obtain } \\
\text { Evidence still limited to preclini- } \\
\text { cal studies }\end{array}$ & $\begin{array}{l}\text { Surgical implantation } \\
\text { High cost } \\
\text { Not easy to obtain }\end{array}$ \\
\hline
\end{tabular}

MSC, mesenchymal stem cell; BM, bone marrow-derived; AD, adipose-derived; S, synovium-derived; hUCB, human umbilical cord blood-derived. 
SCs exhibit similar proliferation capacity and pluripotency as other tissue-derived stem cells, with no immune rejection and ethical issues [72]. Recently, new methods for producing iPSCs without viral vectors to reduce the risk of tumorigenicity have been developed [75].

Nonetheless, to date, limited data exists regarding the in vitro chondrogenic differentiation of iPSCs and the yield of iPSCs is relatively low.

\section{Genetically modified MSCs (engineered MSCs)}

The efficacy of MSCs in vivo may still be low due to poor survival, retention, and engraftment of the cells. Most MSCs often die within the first few hours after in vivo delivery [76]. Therefore, MSCs need to be genetically modified to improve survival, migration, and secretion of growth factors for their application in regenerative medicine [76]. Genetic modification of MSCs is usually achieved through viral vectors [76]. The most commonly used vectors include retrovirus, lentivirus, baculovirus, and adenovirus [22]. Viral transduction has improved homing of MSCs to the defect or inflammation site through the overexpression of homing receptors. MSCs have been transduced with adenovirus expressing C-X-C chemokine receptor 4 (CXCR-4) and runt-related transcription factor-2 (Runx-2), and with retrovirus expressing receptor activator of nuclear factor-kB and CXCR-4 [77,78]. Although the efficacy of genetically modified MSCs has been demonstrated in preclinical studies, it has not been investigated in clinical trials.

\section{Conclusion}

MSCs are the hottest topic in recent stem cell research. The application of stem cells in cartilage regeneration has been tried a lot, but so far, the effect of cartilage regeneration is not consistent from one study to another. Moreover, the most appropriate cell source is still controversial. Further research is needed to determine which tissue-derived stem cells, which usage and dose will be ideal for the treatment of osteoarthritis. In this review, we briefly reviewed the most up-to-date knowledge, including the characteristics, types, and clinical issues of MSCs. It is expected that in future, treatment with MSCs will be applied more clinically in the treatment of knee OA.

\section{Acknowledgments}

\section{Conflicts of interest}

No potential conflict of interest relevant to this article was reported.

\section{Author contributions}

Conceptualization: GBK, OJS; Data curation: GBK; Formal analysis: GBK; Methodology: GBK; Project administration: OJS; Investigation, Resources: GBK; Supervision: OJS; Validation: GBK; Writing-original draft: GBK; Writing-review \& editing: GBK, OJS.

\section{ORCID}

Gi Beom Kim, https://orcid.org/0000-0002-4067-1285

Oog-Jin Shon, https://orcid.org/0000-0002-9123-5694

\section{References}

1. Gupta S, Hawker GA, Laporte A, Croxford R, Coyte PC. The economic burden of disabling hip and knee osteoarthritis (OA) from the perspective of individuals living with this condition. Rheumatology (Oxford) 2005;44:1531-7.

2. de Lange-Brokaar BJ, Ioan-Facsinay A, van Osch GJ, Zuurmond AM, Schoones J, Toes RE, et al. Synovial inflammation, immune cells and their cytokines in osteoarthritis: a review. Osteoarthritis Cartilage 2012;20:1484-99.

3. Vincenti MP, Brinckerhoff CE. Transcriptional regulation of collagenase (MMP-1, MMP-13) genes in arthritis: integration of complex signaling pathways for the recruitment of gene-specific transcription factors. Arthritis Res 2002;4:157-64.

4. Roach HI, Yamada N, Cheung KS, Tilley S, Clarke NM, Oreffo $\mathrm{RO}$, et al. Association between the abnormal expression of matrix-degrading enzymes by human osteoarthritic chondrocytes and demethylation of specific $\mathrm{CpG}$ sites in the promoter regions. Arthritis Rheum 2005;52:3110-24.

5. Martin JA, Buckwalter JA. The role of chondrocyte senescence in the pathogenesis of osteoarthritis and in limiting cartilage repair.J Bone Joint Surg Am 2003;85A(Suppl 2):106-10.

6. Chevalier X, Eymard F, Richette P. Biologic agents in osteoarthritis: hopes and disappointments. Nat Rev Rheumatol 2013;9:400-10.

7. Guler-Yuksel M, Allaart CF, Watt I, Goekoop-Ruiterman YP, de Vries-Bouwstra JK, van Schaardenburg D, et al. Treatment with TNF- $\alpha$ inhibitor infliximab might reduce hand osteoarthritis in patients with rheumatoid arthritis. Osteoarthritis Cartilage 2010;18:1256-62.

8. Hawker GA, Mian S, Bednis K, Stanaitis I. Osteoarthritis year 2010 in review: non-pharmacologic therapy. Osteoarthritis Cartilage 2011;19:366-74.

9. Goyal D, Keyhani S, Lee EH, Hui JH. Evidence-based status of microfracture technique: a systematic review of level I and II studies. Arthroscopy 2013;29:1579-88. 
10. Mithoefer K, McAdams T, Williams RJ, Kreuz PC, Mandelbaum BR. Clinical efficacy of the microfracture technique for articular cartilage repair in the knee: an evidence-based systematic analysis. Am J Sports Med 2009;37:2053-63.

11. Niemeyer P, Porichis S, Steinwachs M, Erggelet C, Kreuz PC, Schmal H, et al. Long-term outcomes after first-generation autologous chondrocyte implantation for cartilage defects of the knee. Am J Sports Med 2014;42:150-7.

12. Martincic D, Radosavljevic D, Drobnic M. Ten-year clinical and radiographic outcomes after autologous chondrocyte implantation of femoral condyles. Knee Surg Sports Traumatol Arthrosc 2014;22:1277-83.

13. Gudas R, Gudaite A, Mickevicius T, Masiulis N, Simonaityte R, Cekanauskas E, et al. Comparison of osteochondral autologous transplantation, microfracture, or debridement techniques in articular cartilage lesions associated with anterior cruciate ligament injury: a prospective study with a 3-year follow-up. Arthroscopy 2013;29:89-97.

14. Jo CH, Lee YG, Shin WH, Kim H, Chai JW, Jeong EC, et al. Intra-articular injection of mesenchymal stem cells for the treatment of osteoarthritis of the knee: a proof-of-concept clinical trial. Stem Cells 2014;32:1254-66.

15. Freitag J, Bates D, Boyd R, Shah K, Barnard A, Huguenin L, et al. Mesenchymal stem cell therapy in the treatment of osteoarthritis: reparative pathways, safety and efficacy. A review. BMC Musculoskelet Disord 2016;17:230.

16. Barry F, Murphy M. Mesenchymal stem cells in joint disease and repair. Nat Rev Rheumatol 2013;9:584-94.

17. Vezina Audette R, Lavoie-Lamoureux A, Lavoie JP, Laverty S. Inflammatory stimuli differentially modulate the transcription of paracrine signaling molecules of equine bone marrow multipotent mesenchymal stromal cells. Osteoarthritis Cartilage 2013;21:1116-24.

18. Jeong SY, Kim DH, Ha J, Jin HJ, Kwon SJ, Chang JW, et al. Thrombospondin-2 secreted by human umbilical cord blood-derived mesenchymal stem cells promotes chondrogenic differentiation. Stem Cells 2013;31:2136-48.

19. Vega A, Martin-Ferrero MA, Del Canto F, Alberca M, Garcia V, Munar A, et al. Treatment of knee osteoarthritis with allogeneic bone marrow mesenchymal stem cells: a randomized controlled trial. Transplantation 2015;99:1681-90.

20. Martin DR, Cox NR, Hathcock TL, Niemeyer GP, Baker HJ. Isolation and characterization of multipotential mesenchymal stem cells from feline bone marrow. Exp Hematol 2002; 30:879-86.

21. Johnson MH, McConnell JM. Lineage allocation and cell polarity during mouse embryogenesis. Semin Cell Dev Biol
2004;15:583-97.

22. Airenne KJ, Hu YC, Kost TA, Smith RH, Kotin RM, Ono C, et al. Baculovirus: an insect-derived vector for diverse gene transfer applications. Mol Ther 2013;21:739-49.

23. Pittenger MF, Mackay AM, Beck SC, Jaiswal RK, Douglas R, Mosca JD, et al. Multilineage potential of adult human mesenchymal stem cells. Science 1999;284:143-7.

24. De Bari C, Dell'Accio F, Tylzanowski P, Luyten FP. Multipotent mesenchymal stem cells from adult human synovial membrane. Arthritis Rheum 2001;44:1928-42.

25. Guilak F, Estes BT, Diekman BO, Moutos FT, Gimble JM. 2010 Nicolas Andry Award: Multipotent adult stem cells from adipose tissue for musculoskeletal tissue engineering. Clin Orthop Relat Res 2010;468:2530-40.

26. Trubiani O, Orsini G, Caputi S, Piatelli A. Adult mesenchymal stem cells in dental research: a new approach for tissue engineering. Int J Immunopathol Pharmacol 2006;19:451-60.

27. Dominici M, Le Blanc K, Mueller I, Slaper-Cortenbach I, Marini F, Krause D, et al. Minimal criteria for defining multipotent mesenchymal stromal cells. The International Society for Cellular Therapy position statement. Cytotherapy 2006;8:315-7.

28. Ra JC, Shin IS, Kim SH, Kang SK, Kang BC, Lee HY, et al. Safety of intravenous infusion of human adipose tissue-derived mesenchymal stem cells in animals and humans. Stem Cells Dev 2011;20:1297-308.

29. Danisovic L, Lesny P, Havlas V, Teyssler P, Syrova Z, Kopani M, et al. Chondrogenic differentiation of human bone marrow and adipose tissue-derived mesenchymal stem cells. J Appl Biomed 2007;5:139-50.

30. Koga H, Shimaya M, Muneta T, Nimura A, Morito T, Hayashi $\mathrm{M}$, et al. Local adherent technique for transplanting mesenchymal stem cells as a potential treatment of cartilage defect. Arthritis Res Ther 2008;10:R84.

31. Orozco L, Munar A, Soler R, Alberca M, Soler F, Huguet M, et al. Treatment of knee osteoarthritis with autologous mesenchymal stem cells: a pilot study. Transplantation 2013;95:1535-41.

32. Wong KL, Lee KB, Tai BC, Law P, Lee EH, Hui JH. Injectable cultured bone marrow-derived mesenchymal stem cells in varus knees with cartilage defects undergoing high tibial osteotomy: a prospective, randomized controlled clinical trial with 2 years' follow-up. Arthroscopy 2013;29:2020-8.

33. Wakitani S, Okabe T, Horibe S, Mitsuoka T, Saito M, Koyama T, et al. Safety of autologous bone marrow-derived mesenchymal stem cell transplantation for cartilage repair in 41 patients with 45 joints followed for up to 11 years and 5 months. J Tissue Eng Regen Med 2011;5:146-50.

34. Davatchi F, Abdollahi BS, Mohyeddin M, Shahram F, Nikbin B. 
Mesenchymal stem cell therapy for knee osteoarthritis. Preliminary report of four patients. Int J Rheum Dis 2011;14:211-5.

35. Davatchi F, Sadeghi Abdollahi B, Mohyeddin M, Nikbin B. Mesenchymal stem cell therapy for knee osteoarthritis: 5 years follow-up of three patients. Int J Rheum Dis 2016;19:219-25.

36. Medical Advisory Secretariat. Osteogenic protein-1 for long bone nonunion: an evidence-based analysis. Ont Health Technol Assess Ser 2005;5:1-57.

37. Madry H, Gao L, Eichler H, Orth P, Cucchiarini M. Bone marrow aspirate concentrate-enhanced marrow stimulation of chondral defects. Stem Cells Int 2017;2017:1609685.

38. Caplan AI, Dennis JE. Mesenchymal stem cells as trophic mediators. J Cell Biochem 2006;98:1076-84.

39. Hernigou P, Mathieu G, Poignard A, Manicom O, Beaujean F, Rouard H. Percutaneous autologous bone-marrow grafting for nonunions: surgical technique. J Bone Joint Surg Am 2006;88(1 Suppl 2):322-7.

40. Centeno C, Pitts J, Al-Sayegh H, Freeman M. Efficacy of autologous bone marrow concentrate for knee osteoarthritis with and without adipose graft. Biomed Res Int 2014;2014:370621.

41. Sampson S, Smith J, Vincent H, Aufiero D, Zall M, Botto-van-Bemden A. Intra-articular bone marrow concentrate injection protocol: short-term efficacy in osteoarthritis. Regen Med 2016;11:511-20.

42. Shapiro SA, Kazmerchak SE, Heckman MG, Zubair AC, O'Connor MI. A prospective, single-blind, placebo-controlled trial of bone marrow aspirate concentrate for knee osteoarthritis. Am J Sports Med 2017;45:82-90.

43. Jin YZ, Lee JH. Mesenchymal stem cell therapy for bone regeneration. Clin Orthop Surg 2018;10:271-8.

44. Raposio E, Bonomini S, Calderazzi F. Isolation of autologous adipose tissue-derived mesenchymal stem cells for bone repair. Orthop Traumatol Surg Res 2016;102:909-12.

45. Bourin P, Bunnell BA, Casteilla L, Dominici M, Katz AJ, March $\mathrm{KL}$, et al. Stromal cells from the adipose tissue-derived stromal vascular fraction and culture expanded adipose tissue-derived stromal/stem cells: a joint statement of the International Federation for Adipose Therapeutics and Science (IFATS) and the International Society for Cellular Therapy (ISCT). Cytotherapy 2013;15:641-8.

46. Patrikoski M, Juntunen M, Boucher S, Campbell A, Vemuri MC, Mannerström B, et al. Development of fully defined xeno-free culture system for the preparation and propagation of cell therapy-compliant human adipose stem cells. Stem Cell Res Ther 2013;4:27.

47. Thirumala S, Gimble JM, Devireddy RV. Cryopreservation of stromal vascular fraction of adipose tissue in a serum-free freez- ing medium. J Tissue Eng Regen Med 2010;4:224-32.

48. Baer PC, Geiger H. Adipose-derived mesenchymal stromal/ stem cells: tissue localization, characterization, and heterogeneity. Stem Cells Int 2012;2012:812693.

49. Gentile P, Calabrese C, De Angelis B, Pizzicannella J, Kothari A, Garcovich S. Impact of the different preparation methods to obtain human adipose-derived stromal vascular fraction cells (ADSVFs) and human adipose-derived mesenchymal stem cells (AD-MSCs): enzymatic digestion versus mechanical centrifugation. Int J Mol Sci 2019;20:5471.

50. Lee WS, Kim HJ, Kim KI, Kim GB, Jin W. Intra-articular injection of autologous adipose tissue-derived mesenchymal stem cells for the treatment of knee osteoarthritis: a phase IIb, randomized, placebo-controlled clinical trial. Stem Cells Transl Med 2019;8:504-11.

51. Pak J, Chang JJ, Lee JH, Lee SH. Safety reporting on implantation of autologous adipose tissue-derived stem cells with platelet-rich plasma into human articular joints. BMC Musculoskelet Disord 2013;14:337.

52. Pers YM, Rackwitz L, Ferreira R, Pullig O, Delfour C, Barry F, et al. Adipose mesenchymal stromal cell-based therapy for severe osteoarthritis of the knee: a phase I dose-escalation trial. Stem Cells Transl Med 2016;5:847-56.

53. Kim YS, Kwon OR, Choi YJ, Suh DS, Heo DB, Koh YG. Comparative matched-pair analysis of the injection versus implantation of mesenchymal stem cells for knee osteoarthritis. Am J Sports Med 2015;43:2738-46.

54. Filardo G, Madry H, Jelic M, Roffi A, Cucchiarini M, Kon E. Mesenchymal stem cells for the treatment of cartilage lesions: from preclinical findings to clinical application in orthopaedics. Knee Surg Sports Traumatol Arthrosc 2013;21:1717-29.

55. Zimmerlin L, Donnenberg VS, Pfeifer ME, Meyer EM, Paault B, Rubin JP, et al. Stromal vascular progenitors in adult human adipose tissue. Cytometry A 2010;77:22-30.

56. Yokota N, Hattori M, Ohtsuru T, Otsuji M, Lyman S, Shimomura $\mathrm{K}$, et al. Comparative clinical outcomes after intra-articular injection with adipose-derived cultured stem cells or noncultured stromal vascular fraction for the treatment of knee osteoarthritis. Am J Sports Med 2019;47:2577-83.

57. Fodor PB, Paulseth SG. Adipose derived stromal cell (ADSC) injections for pain management of osteoarthritis in the human knee joint. Aesthet Surg J 2016;36:229-36.

58. Kubosch EJ, Lang G, Furst D, Kubosch D, Izadpanah K, Rolauffs B, et al. The potential for synovium-derived stem cells in cartilage repair. Curr Stem Cell Res Ther 2018;13:174-84.

59. Sasaki A, Mizuno M, Ozeki N, Katano H, Otabe K, Tsuji K, et al. Canine mesenchymal stem cells from synovium have a 
higher chondrogenic potential than those from infrapatellar fat pad, adipose tissue, and bone marrow. PLoS One 2018;13: e0202922.

60. Kurth TB, Dell'accio F, Crouch V, Augello A, Sharpe PT, De Bari C. Functional mesenchymal stem cell niches in adult mouse knee joint synovium in vivo. Arthritis Rheum 2011;63: 1289-300.

61. Koga H, Muneta T, Ju YJ, Nagase T, Nimura A, Mochizuki T, et al. Synovial stem cells are regionally specified according to local microenvironments after implantation for cartilage regeneration. Stem Cells 2007;25:689-96.

62. Shimomura K, Yasui Y, Koizumi K, Chijimatsu R, Hart DA, Yonetani Y, et al. First-in-human pilot study of implantation of a scaffold-free tissue-engineered construct generated from autologous synovial mesenchymal stem cells for repair of knee chondral lesions. Am J Sports Med 2018;46:2384-93.

63. Klontzas ME, Kenanidis EI, Heliotis M, Tsiridis E, Mantalaris A. Bone and cartilage regeneration with the use of umbilical cord mesenchymal stem cells. Expert Opin Biol Ther 2015; 15:1541-52.

64. Jin HJ, Bae YK, Kim M, Kwon SJ, Jeon HB, Choi SJ, et al. Comparative analysis of human mesenchymal stem cells from bone marrow, adipose tissue, and umbilical cord blood as sources of cell therapy. Int J Mol Sci 2013;14:17986-8001.

65. Park YB, Ha CW, Lee CH, Yoon YC, Park YG. Cartilage regeneration in osteoarthritic patients by a composite of allogeneic umbilical cord blood-derived mesenchymal stem cells and hyaluronate hydrogel: results from a clinical trial for safety and proof-of-concept with 7 years of extended follow-up. Stem Cells Transl Med 2017;6:613-21.

66. Matas J, Orrego M, Amenabar D, Infante C, Tapia-Limonchi R, Cadiz MI, et al. Umbilical cord-derived mesenchymal stromal cells (MSCs) for knee osteoarthritis: repeated MSC dosing is superior to a single MSC dose and to hyaluronic acid in a controlled randomized Phase I/II trial. Stem Cells Transl Med 2019;8:215-24.

67. Ha CW, Park YB, Chung JY, Park YG. Cartilage repair using composites of human umbilical cord blood-derived mesenchymal stem cells and hyaluronic acid hydrogel in a minipig model. Stem Cells Transl Med 2015;4:1044-51.

68. Grigolo B, Lisignoli G, Piacentini A, Fiorini M, Gobbi P, Mazzotti G, et al. Evidence for redifferentiation of human chondro- cytes grown on a hyaluronan-based biomaterial (HYAff 11): molecular, immunohistochemical and ultrastructural analysis. Biomaterials 2002;23:1187-95.

69. Kon E, Verdonk P, Condello V, Delcogliano M, Dhollander A, Filardo G, et al. Matrix-assisted autologous chondrocyte transplantation for the repair of cartilage defects of the knee: systematic clinical data review and study quality analysis. Am J Sports Med 2009;37(Suppl 1):156S-166S

70. Rai V, Dilisio MF, Dietz NE, Agrawal DK. Recent strategies in cartilage repair: a systemic review of the scaffold development and tissue engineering. J Biomed Mater Res A 2017;105:234354.

71. Breitbach M, Bostani T, Roell W, Xia Y, Dewald O, Nygren JM, et al. Potential risks of bone marrow cell transplantation into infarcted hearts. Blood 2007;110:1362-9.

72. Zhu Y, Wu X, Liang Y, Gu H, Song K, Zou X, et al. Repair of cartilage defects in osteoarthritis rats with induced pluripotent stem cell derived chondrocytes. BMC Biotechnol 2016;16:78.

73. Miao Q, Shim W, Tee N, Lim SY, Chung YY, Ja KP, et al. iPSC-derived human mesenchymal stem cells improve myocardial strain of infarcted myocardium. J Cell Mol Med 2014;18: 1644-54.

74. Sareen D, Gowing G, Sahabian A, Staggenborg K, Paradis R, Avalos P, et al. Human induced pluripotent stem cells are a novel source of neural progenitor cells (iNPCs) that migrate and integrate in the rodent spinal cord. J Comp Neurol 2014;522: 2707-28.

75. Trokovic R, Weltner J, Nishimura K, Ohtaka M, Nakanishi M, Salomaa V, et al. Advanced feeder-free generation of induced pluripotent stem cells directly from blood cells. Stem Cells Transl Med 2014;3:1402-9.

76. Park JS, Suryaprakash S, Lao YH, Leong KW. Engineering mesenchymal stem cells for regenerative medicine and drug delivery. Methods 2015;84:3-16.

77. Lien CY, Chih-Yuan Ho K, Lee OK, Blunn GW, Su Y. Restoration of bone mass and strength in glucocorticoid-treated mice by systemic transplantation of CXCR4 and cbfa-1 co-expressing mesenchymal stem cells. J Bone Miner Res 2009;24:837-48.

78. Cho SW, Sun HJ, Yang JY, Jung JY, An JH, Cho HY, et al. Transplantation of mesenchymal stem cells overexpressing RANK-Fc or CXCR4 prevents bone loss in ovariectomized mice. Mol Ther 2009;17:1979-87. 